\title{
Financial Leasing in the Construction Companies in Irbid City
}

\author{
Farouq Ahmad Alazzam \\ E-mail: farouq_20000@yahoo.com
}

Received: December 24, 2014 Accepted: January 7, 2015

doi:10.5296/ber.v5i1.6815 URL: http://dx.doi.org/10.5296/ber.v5i1.6815

\begin{abstract}
This study sought to identify the extent of the presence of the motives of the contracting companies in Irbid city to rely on finance lease and knowledge of the most important administrative, regulatory and financial components of this type of funding, and to identify the most important obstacles -if it available- which restricts it.

The most important findings of this study is the existence of motives for contracting companies in Irbid city to resort to hire finance. Although the interest was relatively large, and there is a need to pledged assets in an exaggerated manner. Also shows that these companies are characterized by regulatory and supervisory and financial viable to do a finance lease.

This study found that the most important obstacles facing the contracting companies it is the lack of sufficient financial to finance companies using the financial leasing system, and that many of the assets used by contracting companies do not receive sufficient turnout by these financial companies.

This study recommended financial firms that practice financial leasing to study interest rates and try to be reduced, in addition to ease the strict in pledged assets process, particularly on the construction companies in Irbid city. Also it recommended the concerned authorities to encourage the formation and create more financial firms to finance by using financial leasing system. This study recommended to take advantage of elements, whether owned by the financial regulatory and supervisory to persuade financial firms that practice financial leasing financed within interest rate.
\end{abstract}

Keywords: Leasing, Construction companies, Irbid, Alazzam

\section{Introduction}

To identify sources of funding as an amount or sort of any facility is considered one of the first things that can be thinking of the founding, one of the most important decisions that can be taken, because of their great effects on the present and the future of the facility. To take funding 
decision needs of internal and external accurate information until it is making the right decision in light of the alternatives available and possible funding sources. By the vision of the administration, the particular source is the best, but under the current circumstances can not provide this source either because of internal factors of the facility where they can not meet this source requirements such as cost or appropriate financial position required by this source, or because lack of this source in the available market.

It is relatively new sources of funding, which requires certain things and circumstances that some facilities may fail to meet them is the financial leasing system, which can not deliver a turnout of some financial companies. And resort to this system needs to desire defended by the entity in addition to some of the financial, administrative and regulatory elements.

This study will look into this important source of funding and trying to figure caught in contracting companies in Jordanian Irbid city hoping that this study represents a modest building block for the development of these companies in order to rise to this beloved province.

\section{Study Problem}

A study problem is the lack of knowledge of the reality of financial leasing in contracting companies in Irbid city, where the question is asked about the existence of the motives for these companies to resort to hire finance. Will there elements of administrative, regulatory, financial, and whether there are obstacles to limit this kind of lease.

\section{Objective of Study}

This study aimed to shed light on the subject of finance lease and the extent of the presence of motives of contracting companies in Irbid city to rely on finance lease. And know if there are elements of administrative and financial monitoring and finance for hire, and to identify the obstacles that limit this type of leasing.

\section{Previous Studies}

Shamaly study (2013), it is aimed to exploration of the possibility of implementation of financial leasing in construction industry companies as lessees and banks as lessor. The study reach to set of results, such as: organizational, financial, and financing ability of implementation of leasing is existing in both construction industry companies and banks, as well as desire of implementation of leasing and There are some limitation that limited of use the leasing, such as luck of companies that operate in the field of leasing in Palestine.

Nemati Study (2012), This study aimed to clarify the financial leasing system in terms of its definition and its components, types and development historically and how to calculate the rent based on the traditional method and the method of time value of money. The study found that the return on investment by way of the time value of money is higher than by the traditional method, and use the method downward gradient leads to address the financial situation.

Othman study (2011): This study aimed to indicate the role of financial leasing in the activation of railways transport projects, also this study found that financial leasing provides a source of funding and the cost is relatively low, especially in developing countries. These countries can 
engage the private sector to invest in the railway sector. This study recommended studying international experience in the field of financial leasing for the development of a legislative framework and appropriate legal, and encourage the establishment of private companies renting capital assets in general and especially in the transport sector.

Barood study (2011), The study aimed to investigate the determents of applied financial easing as implement to fund the economical enterprises. The study found that the Non-depository financial institutions have knowledge of financial leasing, but do not make training courses for our employees to support applied the financial leasing, and thing that the leasing have high risks because it for long-term, and without law to organize the relation ship between the Lessors and Lessees in the financial leasing, the Non-depository financial institutions can't used this system.

Al-Shiab, and Bawnih Study (2008), This study aimed to develop a statement determinants financial leasing system in Jordan, and this study found that there are limitations concerning legislation and the lack of incentives for the application of this system and deal with companies. This study recommended that the promotion and dissemination of the idea of financial leasing between the Jordanian companies.

Siam and Qutaishat Study (2007), This study aimed to describe the effects of financial leasing on the financial performance of charter companies in Jordan, and the study found that the effect was positive by increasing cash, profitability and reduce risk and this is what such a motivation for some companies to come somewhat on the use of financial leasing in Jordan. And the most important that recommended by the study is to encourage companies to greater dependence on financial leasing because of its benefits.

\section{Hypotheses and Question of the Study}

First hypothesis: There is motivated to contracting companies in the city of Irbid to resort to finance lease.

Second hypothesis: There are regulatory elements and monitoring of finance lease with the contracting companies in the city of Irbid.

Third hypothesis: there are financial elements of finance lease with the contracting companies in the city of Irbid.

Study Question: What are the constraints limit of finance lease with the contracting companies in the city of Irbid?

\section{The Stability of the Tool}

This study has been testing the stability of the tool by Cronbach's coefficient alpha testing, Table 1 shows that all values greater than 0.60 then there is stability in the study tool.

Table 1. Cronbach's alpha values for the study dimensions

\begin{tabular}{|l|l|}
\hline Dimension & Cronbach's alpha \\
\hline Motivate & 0.79 \\
\hline
\end{tabular}




\begin{tabular}{|l|l|}
\hline regulatory elements and monitoring & 0.72 \\
\hline financial elements & 0.84 \\
\hline Constraints & 0.75 \\
\hline
\end{tabular}

\section{Description Personal and Functional Factors}

Can be seen from Table 2

Age:That accounted for $30.29 \%$ of the sample who are equal to over the age of 55 years, and $22.35 \%$ of those aged between 26 and less than 36, and $20.88 \%$ between the ages of 46 - and less than 55 years, and $17.35 \%$, ranging the ages of 36 - and less than 45 , and $9.12 \%$ is equal to or less than the age of 25 .

Qualifications:That accounted for $45.49 \%$ of the study sample who hold a bachelor's degree, and $24.71 \%$ of those who have an average diploma, and $12.65 \%$ have a master's degree, and $7.06 \%$ less secondary, and accounted for $5.29 \%$ of them hold doctorate degree, and $5.00 \%$ of respondents operators have higher diploma.

Job description:That accounted for $37.06 \%$ of the staff, and $25.88 \%$ of the Heads of Departments, and $18.53 \%$ of deputies managers, and $11.76 \%$ of the general directors, and $6.76 \%$ from other titles.

Specialization:That accounted for $32.06 \%$ of respondents Accounting specialization, and $19.12 \%$ of specialization Business Administration, and $13.82 \%$ of specialization financial, and $9.12 \%$ of specialization economy, and $25.88 \%$ from other disciplines or without university disciplines.

Table 2. Factors and percentages of respondent's personal variables

\begin{tabular}{|l|l|r|r|}
\hline Factor & Element & Freq & $\%$ \\
\hline \multirow{4}{*}{ age } & equal to or less than the age of 25 & 31 & 9.12 \\
\cline { 2 - 4 } & 26 - less than 36 & 76 & 22.35 \\
\cline { 2 - 4 } & 36 - less than 45 & 59 & 17.35 \\
\cline { 2 - 4 } & 45 - less than 55 & 71 & 20.88 \\
\cline { 2 - 4 } & Equal or over than 55 & 103 & 30.29 \\
\hline \multirow{5}{*}{ Qualifications } & average diploma & 84 & 24.71 \\
\cline { 2 - 4 } & bachelor's degree & 154 & 45.29 \\
\cline { 2 - 4 } & higher diploma & 17 & 5.00 \\
\cline { 2 - 4 } & master's degree & 43 & 12.65 \\
\cline { 2 - 4 } & doctorate degree & 18 & 5.29 \\
\cline { 2 - 4 } & less secondary & 24 & 7.06 \\
\hline
\end{tabular}




\begin{tabular}{|l|l|r|r|}
\hline \multirow{5}{*}{ Job description } & Directors & 40 & 11.76 \\
\cline { 2 - 4 } & deputies managers & 63 & 18.53 \\
\cline { 2 - 4 } & the Heads of Departments & 88 & 25.88 \\
\cline { 2 - 4 } & Staff & 126 & 37.06 \\
\cline { 2 - 4 } & other titles & 23 & 6.76 \\
\hline \multirow{5}{*}{ Specialization } & financial & 47 & 13.82 \\
\cline { 2 - 4 } & Accounting & 109 & 32.06 \\
\cline { 2 - 4 } & economy & 31 & 9.12 \\
\cline { 2 - 4 } & Business Administration & 65 & 19.12 \\
\cline { 2 - 4 } & Others & 88 & 25.88 \\
\hline
\end{tabular}

8. Test of Hypothesis

\subsection{First Hypothesis}

There is motivated to contracting companies in the city of Irbid to resort to hire finance.

Table 3 shows the (private motives) that except for paragraphs No. 1.5. All other paragraphs on each unit got circles of calculation is greater than 3.00, and the levels of significance Show less than 0.05 , and this indicates that all statistically significant. And replaced paragraph 4 which relates not to force companies to bear in advance to obtain financing from banks using the financial leasing system, first prize and a mean 4.49 batch, followed by the paragraph number 6 and a mean 4.15, then paragraphs No. 7, 2.9, 8, respectively, paragraph 3and measures the extent to which companies get flexible financing from banks using the financial leasing system came, the last rank within paragraphs statistically acceptable.

Paragraph No. 1, it has been calculated on the center of my less than 3.00 is, they are not statistically significant. In other words, interest the relatively large financial leasing.

Paragraph No. 5 and, although they have got to the middle of my larger than 3.00, but it's got a level of significance greater than 0.05 scenes that is, they are not statistically significant. That there is no need to pledged a lot of assets to obtain financing from banks using the financial leasing system.

And reached the arithmetic mean of the combined paragraphs 3.64 and is larger than 3.00 , and the significance level seen less than 0.05 , it is statistically significant, which means that he is the first to accept the hypothesis that there is no motivation for contracting companies in the city of Irbid to resort to hire finance.

There are motivated to contracting companies in the city of Irbid to resort to finance lease. Where companies can obtain financing using financial leasing shortly and flexible system, not be forced to pay an advance for funding, and it can get accurate and clear information from the 
banks about the financial leasing system. Financial leasing gives tax savings system and provides adequate liquidity. But interest the relatively large financial leasing, and there is a need for pledged assets in an exaggerated manner to get this funding

Table 3. Arithmetic mean, standard deviation, $t$ value and the level of significance to motivate

\begin{tabular}{|c|c|c|c|c|c|}
\hline $\begin{array}{l}\text { Item } \\
\text { No }\end{array}$ & Item & $\begin{array}{l}\text { Arith } \\
\text { mean }\end{array}$ & Std.dev & $\begin{array}{c}\mathrm{T} \\
\text { value }\end{array}$ & Sig \\
\hline 1 & interest the relatively small financial leasing & 2.98 & 1.09 & -0.29 & 0.68 \\
\hline 2 & company can obtain financing using financial leasing shortly & 3.77 & 0.99 & 9.90 & 0.00 \\
\hline 3 & $\begin{array}{l}\text { company can get flexible financing from banks using the leasing } \\
\text { system }\end{array}$ & 3.28 & 1.05 & 3.45 & 0.00 \\
\hline 4 & company not be forced to pay an advance for funding & 4.49 & 0.88 & 21.62 & 0.00 \\
\hline 5 & $\begin{array}{l}\text { there is no need for pledged assets in an exaggerated manner to } \\
\text { get this funding }\end{array}$ & 3.04 & 1.01 & 1.781 & .077 \\
\hline 6 & $\begin{array}{c}\text { company get accurate and clear information from the banks } \\
\text { about the financial leasing system }\end{array}$ & 4.15 & 0.66 & 22.42 & 0.00 \\
\hline 7 & Financial leasing gives tax savings system & 4.01 & 0.85 & 15.02 & 0.00 \\
\hline 8 & provides adequate liquidity & 3.45 & 0.91 & 6.28 & 0.00 \\
\hline 9 & $\begin{array}{l}\text { The company may trade-off between the purchase and lease } \\
\text { financing in an objective and accurate alternatives }\end{array}$ & 3.65 & 0.58 & 14.09 & 0.00 \\
\hline & Total & 3.64 & 0.61 & 9.47 & 0.00 \\
\hline
\end{tabular}

\subsection{Second Hypothesis}

There are regulatory elements and monitoring of finance lease with the contracting companies in the city of Irbid.

Table 4 shows the (private regulatory and supervisory tenets) that all the paragraphs on each unit got circles of calculation is greater than 3.00, and the levels of significance Show less than 0.05 , and this indicates that all statistically significant. And replaced paragraph No. 13and measure the extent of the application of the company's accounting system effective responsibility and efficient, first prize and a mean of 3.87, followed by the paragraph number 11 and a mean of 3.85 , then paragraphs No. 10.14, respectively, and came paragraph No. 12and measure the extent of the existence of a transparent and clear regulatory system in companies, the last rank.

And reached the arithmetic mean of the combined paragraphs 3.76 and is larger than 3.00, and the significance level seen less than 0.05 , it is statistically significant, which means that he is accepting the second hypothesis, that there is no regulatory elements and monitoring of the rental finance with the contracting companies in the city of Irbid.

Table 4. Arithmetic mean, standard deviation, $t$ value and the level of significance to regulatory elements and monitoring 


\begin{tabular}{|c|c|c|c|c|c|}
\hline $\begin{array}{c}\text { Item } \\
\text { No }\end{array}$ & Item & Arith mean & Std.dev & $\mathrm{T}$ value & sig \\
\hline 10 & $\begin{array}{l}\text { company apply quality } \\
\text { standards }\end{array}$ & 3.73 & 1.42 & 1.82 & 0.00 \\
\hline 11 & $\begin{array}{l}\text { Company have effective } \\
\text { monitoring systems }\end{array}$ & 3.85 & 1.13 & 2.90 & 0.00 \\
\hline 12 & $\begin{array}{l}\text { Company have, transparent and } \\
\text { clear monitoring systems }\end{array}$ & 3.53 & 1.29 & 1.92 & 0.02 \\
\hline 13 & $\begin{array}{l}\text { company apply these companies } \\
\text { accountable effective } \\
\text { responsibility and efficient } \\
\text { system, }\end{array}$ & 3.87 & 1.48 & 3.21 & 0.00 \\
\hline 14 & $\begin{array}{l}\text { there is clarity and separation of } \\
\text { responsibilities and } \\
\text { administrative and functional } \\
\text { authorities there }\end{array}$ & 3.81 & 1.10 & 1.99 & 0.02 \\
\hline & Total & 3.76 & 0.74 & 12.72 & 0.00 \\
\hline
\end{tabular}

\subsection{Third Hypothesis}

There are financial elements of finance lease with the contracting companies in the city of Irbid.

Table 5 shows that all the paragraphs on each unit got circles of calculation is greater than 3.00, and the levels of significance Show less than 0.05, and this indicates that all statistically significant. And replaced paragraph No. 15and relate to the fact that the liquidity ratios in the company's reassuring for funding using the financial leasing system, first rank and a mean 4.03, followed by the paragraph number 17 and a mean 4.02, then paragraph No. 16, came paragraph No. 18and measure the adequacy of the reserves available to the companies to meet any unforeseen circumstances, the last rank with a mean of 3.89 .

And reached the arithmetic mean of the combined paragraphs 3.97 and is larger than 3.00, and the significance level seen less than 0.05 , it is statistically significant, which means that he is accepting the third hypothesis, that there is any financial elements of the rental finance with the contracting companies in the city of Irbid.

Table 5. Arithmetic mean, standard deviation, $\mathrm{t}$ value and the level of significance to financial elements

\begin{tabular}{|c|l|l|l|l|l|}
\hline $\begin{array}{c}\text { Item } \\
\text { No }\end{array}$ & \multicolumn{1}{|c|}{ Item } & $\begin{array}{l}\text { Arith } \\
\text { mean }\end{array}$ & Std.dev & $\begin{array}{c}\text { T } \\
\text { value }\end{array}$ & sig \\
\hline 15 & $\begin{array}{l}\text { liquidity ratios in reassuring company to obtain financing } \\
\text { by financial leasing system }\end{array}$ & 4.03 & 0.86 & 10.03 & 0.00 \\
\hline 16 & $\begin{array}{l}\text { profitability ratios reassured and can cover the cost of fixed } \\
\text { assets and profitably }\end{array}$ & 3.95 & 1.35 & 4.47 & 0.00 \\
\hline
\end{tabular}




\begin{tabular}{|c|c|c|c|c|c|}
\hline 17 & $\begin{array}{l}\text { company does not face a problem in the collection of most } \\
\text { of the dues }\end{array}$ & 4.02 & 0.94 & 9.18 & 0.00 \\
\hline 18 & $\begin{array}{l}\text { reserves available to the company sufficient to meet any } \\
\text { sudden circumstances. }\end{array}$ & 3.89 & 1.18 & 3.79 & 0.00 \\
\hline & Total & & 0.66 & 10.16 & 0.00 \\
\hline
\end{tabular}

\section{Answer of Study Question}

What are the constraints limit of finance lease with the contracting companies in the city of Irbid?

Table 6 shows that paragraphs 19 and 23 had obtained at the arithmetic mean larger than 3.00 and levels of significance Show less than 0.05, indicating that they were statistically significant. Which means that he does not have enough financial firms to finance the company using the financial leasing system, and many of the assets used by contracting companies do not receive sufficient turnout by financial companies financed by financial leasing system.

The rest of the paragraphs has got circles of calculation is less than 3.00 is, they are not statistically significant, meaning that the local laws in force do not stand a barrier in front of the leasing process and financing, and that the tax laws do not limit the financial leasing process, and that companies that finance lease abide by its commitments in terms of the quality of the original.

Table 6. Arithmetic mean, standard deviation, $\mathrm{t}$ value and the level of significance to constraints

\begin{tabular}{|c|c|c|c|c|c|}
\hline Item No & Item & $\begin{array}{l}\text { Arith } \\
\text { mean }\end{array}$ & Std.dev & $\begin{array}{c}\mathrm{T} \\
\text { value }\end{array}$ & sig \\
\hline 19 & $\begin{array}{l}\text { a lack of sufficient financial finance companies using the } \\
\text { financial leasing system }\end{array}$ & 3.37 & 1.02 & 2.56 & 0.00 \\
\hline 20 & $\begin{array}{l}\text { Local laws in force does not stand obstacle to financing the } \\
\text { leasing process }\end{array}$ & 2.36 & 0.96 & -8.45 & 0.00 \\
\hline 21 & the tax laws do not limit the financial leasing process & 2.15 & 1.00 & -10.76 & 0.00 \\
\hline 22 & $\begin{array}{l}\text { companies that finance lease abide by its commitments in } \\
\text { terms of the quality of the original }\end{array}$ & 2.18 & 0.88 & -11.92 & 0.00 \\
\hline 23 & $\begin{array}{l}\text { many of the assets used by contracting companies do not } \\
\text { receive sufficient turnout by financial companies financed by } \\
\text { leasing system finance. }\end{array}$ & 3.54 & 1.18 & 5.86 & 0.00 \\
\hline
\end{tabular}




\section{Results}

The study found the following

There are motivated to contracting companies in the city of Irbid to resort to finance lease. Where companies can obtain financing using financial leasing shortly and flexible system, not be forced to pay an advance for funding, and you can get accurate and clear information from the banks about the financial leasing system. Financial leasing gives tax savings system provides adequate liquidity. But interest the relatively large financial leasing, and there is a need for pledged assets in an exaggerated manner to get this funding.

There are regulatory elements and monitoring of finance lease with the contracting companies in the city of Irbid, where companies apply quality standards, and there are effective, transparent and clear monitoring systems, and apply these companies accountable effective responsibility and efficient system, and there is clarity and separation of responsibilities and administrative and functional authorities there.

There are financial elements of finance lease with the contracting companies in the city of Irbid, where liquidity ratios in reassuring companies to obtain financing by financial leasing system, as well as profitability ratios reassured and can cover the cost of fixed assets and profitably, and the company does not face a problem in the collection of most of the dues so that does not affect the possibility to meet the expansion needs, and reserves available to the Company sufficient to meet any sudden circumstances.

There are some obstacles faced by contracting companies in the city of Irbid and that limit their reliance on financial leasing, first of all a lack of sufficient financial finance companies using the financial leasing system, and that many of the assets used by contracting companies do not receive sufficient turnout by financial companies financed by leasing system finance.

Local laws in force does not stand obstacle to financing the leasing process, and that the tax laws do not limit the financial leasing process, and that companies that finance lease abide by its commitments in terms of the quality of the original.

\section{Recommendations}

The study recommends the following:

The financial corporations that practice financial leasing study interest rates and try to reduce, if possible, especially on contracting companies in the city of Irbid.

The financial corporations that practice financial leasing alleviate militancy in the process of pledged assets and the private contracting companies in the city of Irbid.

The official authorities encourage the formation and create more financial firms to finance using the financial leasing system.

The financial corporations that practice financial leasing more turnout at financing assets used by contracting companies in the city of Irbid and in particular it has the financial, organizational and regulatory elements sufficient to guarantee the rights of these financial 
companies.

Construction companies in the city of Irbid work to bring more funding by financial leasing system through negotiations with financial corporations that practice financial leasing to persuade funded and within the interest rate taking advantage of elements, whether owned by the financial regulatory and supervisory.

\section{References}

Al-Shiab, mahammad Salam, \& Bawnih, Shamsi, Determinants of Financial Leasing Development in Jordan , 2008 ,Mu'tah University, Jordan.

Barood, ahmed, Obstacles to the application of leasing system as a tool to finance economic projects in the non-banking institutions in Palestine, Palestine, 2011, Unpublished MA, Islamic University - Gaza, http://library.iugaza.edu.ps/thesis.aspx.

Coughlon.J.W, Regulation Rents and Residuals: The FASB Statement in Leasing,1980 ,The Journal of Accountancy.

Donald, Kieso, and Jerry, Weygandt, Intermediate Accounting, 10th ed,2001, New York, John Wiley \& Sons, Inc.

International Accounting Standard Board, International Financial Reporting Standerd- Part A, 2011, London, United Kingdam

Nemate, Ali \& Nemate, Yadollah, Leasing And Comparison Between The Different Leasing Rental Calculation In Iran, International Journal Of Business And Management, 2012, 7(8), 80-87.

Osman, Bassam, Leasing and its role in activating the railway projects, Damascus University Journal of economic and legal sciences 0.2011, 27(3), 601-628.

Shamaly, Mohammed, The Extent of the Possibility of Implementing the Financial Leasing Style in Banks and Construction Industry Companies Operating in the Gaza Strip Empirical Study, $013 . \quad$ Unpublished MA, Islamic University-Gaza, http://library.iugaza.edu.ps/thesis.aspx.

Siam, Zechariah, and Qutaishat, Mohammed, the impact of financial leasing services to the financial performance of the companies rented decisions in Jordan, studies, 2007, folder 34(1), http://dspace.ju.edu.jo/xmlui/handle/123456789/160475

World Leasing Yearbook, 31st edition, Euromoney Trading Ltd, 2011, New York.

\section{Copyright Disclaimer}

Copyright for this article is retained by the author(s), with first publication rights granted to the journal.

This is an open-access article distributed under the terms and conditions of the Creative Commons Attribution license (http://creativecommons.org/licenses/by/3.0/). 